\title{
Determining the Authenticity of Artifacts by Oxygen Isotope Analysis
}

\author{
Joel Kronfeld ${ }^{1}$, Amnon Rosenfeld ${ }^{2}$, Howard R. Feldman ${ }^{3}$ \\ ${ }^{1}$ Department of Geophysics and Planetary Sciences, Tel Aviv University, Tel Aviv, Israel \\ ${ }^{2}$ Geological Survey of Israel (Emeritus), Jerusalem, Israel \\ ${ }^{3}$ Division of Paleontology (Invertebrates), American Museum of Natural History, New York, USA \\ Email: feldspar4@optonline.net
}

Received June 6, 2013; revised July 6, 2013; accepted July 16, 2013

Copyright (C) 2013 Joel Kronfeld et al. This is an open access article distributed under the Creative Commons Attribution License, which permits unrestricted use, distribution, and reproduction in any medium, provided the original work is properly cited.

\begin{abstract}
A technique used to determine the authenticity of artifacts that compares the oxygen isotopic composition of speleothems to the carbonate included within the patina of unprovenanced artifacts is of questionable value. The unprovenanced Jehoash Inscription Tablet and James Ossuary are of potentially immense historical and cultural importance. Nevertheless, they both were rejected by workers based on the oxygen isotope technique which provided the major foundational evidence of forgery in the longest running archaeological trial in Israel. Nevertheless, both these artifacts were determined not to be forged. The initial incongruence between the oxygen isotopes of the speleothems of the Soreq cave (Israel) purported to represent the unique composition of Jerusalem rainfall, and the patina on the artifacts, can be readily explained by the accretion of materials and geo-biochemical processes expected in normal patina formation in the Jerusalem region. The patina formation involves sporadic events in disequilibrium kinetic processes that are opposed to the equilibrium formation of speleothems in a sealed cave. Moreover, 23 of 56 patina samples (41\%) on well-documented ancient artifacts from Israel yielded oxygen isotope values greater or lower than the expected speleothem values of $-4 \delta^{18} \mathrm{O} \%$ [PDB] ${ }_{\text {[P }}-6 \delta^{18} \mathrm{O} \%$ [PDB]. Thus, the speleothem-patina correlation is invalid and the applied oxygen isotopes technique for determining the authenticity of patinas on artifacts is not a useful tool in the authentication of artifacts.
\end{abstract}

Keywords: Oxygen Isotope; Patina; Artifact; Archaeology; Speleothem

\section{Introduction}

An authenticity technique, one that compares the stable isotopic composition of the speleothems in the Soreq Cave (Judean foothills, Israel) to the carbonate included within the patina of the unprovenanced Jehoash Inscription Tablet (JI) and the James Ossuary (JO) was used to indicate that their inscriptions are not genuine artifacts $[1,2]$. Both artifacts, if proved authentic, would have immense historical, cultural and religious implications.

Archaeological artifacts from the Holy Land, especially those that can be used for Biblical historicity, have academic and theological values. Unfortunately $90 \%$ of the artifacts in Israel including the West Bank were and are being looted (acknowledged in the Media by the Anti-Theft Department of the Israel Antiquities Authority (IAA)). We believe that all of these unprovenanced archaeological artifacts should not be ignored because of their unknown origins. Rather, they must be carefully investigated and the assessment of their authenticity should be debated by the scholarly community. Artifacts that have come to the market, collectors and to museums outside the framework of a formal archaeological excavation can still be of immense importance, provided that they are authentic. The Dead Sea Scrolls would be a prime example of one such an unprovenanced find. Thus, the ability to authenticate the unprovenanced material would enable historical studies to be based upon a much larger data set. A recent example of an attempt to develop such a technique is based on oxygen isotopic analyses of carbonate included within the patina of an artefact $[1,2]$. This oxygen isotopic technique had provided the IAA the major foundational evidence for the purported forgery of the JO and the JI. The JO is an ossuary made of soft limestone dated to the first century CE, inscribed "James son of Joseph brother of Jesus". It was authenticated by the epigraphist Lemaire $[3,4]$ and was archaeometrically studied by [5-7]. The JI is a rec- 
tangular dark grey sandstone tablet $(31 \times 25 \times 9 \mathrm{~cm})$ engraved with 16 lines dated to the $8^{\text {th }}-9^{\text {th }}$ century BCE. The inscription commemorates the renovation of the First Temple carried out by King Jehoash, who reigned at the end of the $9^{\text {th }}$ century BCE, ca. 2800 years BP. The philology of the inscription was studied by Sasson [8] and Cohen [9], and its archaeometric examination was researched by Ilani et al. [10,11]. The trial resumed (March $14^{\text {th }}, 2012$ ) by rejected the underpinning of the prosecution's claim that these two artifacts were forged $[12,13]$. However, this oxygen isotopic technique is not employed in any laboratory in the world. In addition, this technique was not tested on patinas from officially excavated artifacts.

A detailed archaeometric study on the JO and JI inscription patinas and its host materials has been performed at the Geological Survey of Israel $[5-7,10,14]$ which strengthens the contention that both inscriptions are authentic. Moreover, the newly revised study by the originators of this oxygen isotope tool [15] yielded more negative values for Jerusalem rainfall during the Roman-Byzantine periods, actually contradicting their evidence of forgery.

\section{Methods}

The mineralogic composition of the rocks and patinas both of the JI and JO were determined in the laboratories of the Geological Survey of Israel by using a transmitting ore mineral microscope a stereoscopic binocular (magnification up to $\times 50$ ) and a Philips X-ray diffractometer. Samples were removed by using a diamond-tipped hand drill and from the patinas by peeling with a sharp steel blade. A scanning electron microscope (SEM, JEOL840 ), equipped with an energy dispersive spectrometer (EDS, Oxford-Link-Isis) was employed for detailed inspection of the physical properties and structural features of the rocks and patinas, as well as for chemical analysis. A Hitachi S-3200N SEM with low vacuum was used for further analyses of microorganism content within the patina layers. Additional geochemical analyses were carried out using inductively coupled plasma atomic emission spectroscopy (ICP-AES) $[5,10,11,14]$.

\section{Results}

The oxygen isotope technique $[1,2,16,17]$ that has had the most influence on the authenticity decision debate is actually one that most of the experts in isotopes have had the least experience with and many professionals in the liberal arts are not familiar with the technique. One may expect, considering the importance of the artifacts and the importance of the scientific members of the IAA committees, that a robust and unambiguous data set would have been presented, backing up the newly oxy- gen isotopic authenticity method. Such was far from the case. This technique sounds scientific however the entire isotopic data base had not been released. Patinas in officially excavated artifacts were examined only from 3 items from one location by the researchers [1] which statistically could not support this method.

The method that was to validate provenance, and thus authenticity, compared the oxygen isotopic values preserved in dated stalagmites from the Soreq Cave $[18,19]$ to the oxygen isotopic values in the patina from artifacts purported to come from Jerusalem. The method compared oxygen isotopic data from stalagmites to the oxygen isotopic values in the patina that had developed upon the surface of the JI Tablet [2] and from the patina in the surface and the grooves of the incised lettering of the ossuary [1]. The underlying idea is that the speleothems, provided that they have formed under equilibrium conditions, will preserve the isotopic signature of the drip water of the cave, which itself is a reflection of the local rainfall. The chemistry of speleothem (calcium carbonate crystals of stalactites and stalagmites) formation is well known $[20,21]$. Once deposited there are no subsequent isotopic changes over time until the material is sampled. The oxygen isotopic values of the speleothems are related to the oxygen isotopic values of the cave's drip water which in turn are related to the groundwater values and the isotopic composition of the local precipitation. If the average annual temperature at the surface is known, then temperature changes can be deduced for the period of time that the speleothem had been growing. The oxygen isotopic composition of rain and groundwater has been studied in Israel. It is found that the hydrogen and oxygen isotopes in modern precipitation are delineated by a specific mutual relationship that forms the Eastern Mediterranean Water Line [22]. Modern rainfall in the Middle East is restricted to the winter months. Though minor inputs from the Red Sea are contributors, the dominant moisture source for central Israel is the Mediterranean Sea [23] whose oxygen isotopic composition has remained the same for at least the past two millennia [24]. The isotopic fraction processes of oxygen in the hydrologic cycle are well known [25-27]. The rainfall recharge parameters immediately above the Soreq cave are sufficiently documented [18] so that the rainfall/ oxygen isotope changes can be quantified in $\delta^{18} \mathrm{O} \%$ [SMOw]. It was proposed that for every $280 \mathrm{~mm}$ deviation from the annual mean there will be a concomitant change of $1 \%$ in the $\delta^{18} \mathrm{O}$. The oxygen isotopic values of rain in Israel, reported in the delta per mil notation compared to the Standard Mean Ocean Water (SMOW) have been extensively measured. The IAEA World Meteorological monitoring data base [28] places the modern average annual rainfall for Israel in the range of $-4 \delta^{18} \%$ to -6 $\delta^{18} \mathrm{O} \%$ [smow]. The amount of ${ }^{18} \mathrm{O}$ decreases (the $\delta^{18} \mathrm{O} \%$ 
[SMOW] ) and becomes more negative in a predictable manner as rain falls further northward. Not only do speleothems (stalactites and stalagmites) preserve the oxygen isotopic signature of past rainfalls as they grow, they are readily amenable to absolute dating by the radiocarbon and by the uranium/thorium methods. Working with the assumption that their changes in $\delta^{18} \mathrm{O} \%$ can be translated into rainfall values it was claimed that the speleothems recorded very precise rainfall proxy. Thus the rainfall proxy data for Jerusalem, in the form of oxygen isotopic values preserved in stalagmites, were reported from the Holocene into the Pleistocene [19]. Alternative proposals that related isotopic changes to a source effect $[29,30]$ rather than reflecting to the changes in local rainfall appear to have been dismissed out of hand. Kolodny [31] make a particularly cogent argument that the $\delta^{18} \mathrm{O}$ variations recorded in the speleothems are a result of isotopic variability in the moisture source rather than changes in precipitation over the cave. Be that as it may, extrapolations [32] were made to the chronologically broadly spaced data to demonstrate that the average Jerusalem rainfall for the last 3000 years was invariant and confined to the range of $-4 \delta^{18} \mathrm{O} \%$ to $-6 \delta^{18} \mathrm{O} \%$ [SMOW] as it is today. From this extrapolation the assertion was drawn determining the annual rainfall in the Jerusalem area for the last 3000 years to approximately $500 \mathrm{~mm}$. Thus, it was asserted that a new method for determining authenticity of artifacts purported to be from Jerusalem region was available. It was based on the assumption that carbonate included in the patina of genuine artifacts should not deviate from values correlative to rainfall of $-4 \delta^{18} \mathrm{O} \%$ to $-6 \delta^{18} \mathrm{O} \%$ [PDB]. The geographic latitude of its "true" provenance would be related to the amount that the values deviated from Jerusalem rain. More negative values would imply more northern latitudes, and vice versa.

The oxygen isotopic method described in Ayalon [1] has never been used to test for the authenticity of artifacts. Thus, when samples of patina were taken from the surface of the JI and the JO not all of the oxygen isotopic analyses fell in the range deemed to be the acceptable values for carbonates precipitated from Jerusalem rains $\left(-4 \delta^{18} \mathrm{O} \%\right.$ to $-6 \delta^{18} \mathrm{O} \%{ }_{[\mathrm{PDB}]}$; Figure 1, \#1). Two oxygen isotope samples of the carbonate taken from the patina on the JI were too negative $\left(-7.3 \delta^{18} \mathrm{O} \%\right.$ and -8.4 $\delta^{18} \mathrm{O} \%{ }_{[\mathrm{PDB}]}$; Figure 1, \#2), and two samples were too positive $\left(-1.7 \delta^{18} \mathrm{O} \%\right.$ and $-0.9 \delta^{18} \mathrm{O} \%$ [PDB] $)$ according to their model. Whereas oxygen isotopic values from the patina of the JO included several values that are more depleted $\left(-7.48 \delta^{18} \mathrm{O} \%\right.$ o to $-10.20 \delta^{18} \mathrm{O} \%$ [PDB]; Figure 1, \#3) than the speleothems. From these values they determined that there was incontrovertible proof of fraud and forgery.

Ayalon [1] offered a scenario explaining how this may have been carried out. This involved dissolving ground limestone in hot $\left(50^{\circ} \mathrm{C}\right)$ Jerusalem tap water while adding a mixture of components that supported the authenticity of the artifacts [11]. The slurry was added and fixed to the surface of the recently made inscriptions to create an artificial patina. This is the totality of the isotopic and chemical basis of the case against authenticity. However, there are underlying errors in their assumptions and methodology. In addition, natural patina growth in buried environments invalidates this technique.

A recent publication [15] further weakens the forgery argument. And surprisingly this case is presented by those who were most adamant that the rainfall in Jerusalem was invariantly restricted to the range of $-4 \%$ o to -6 $\delta^{18} \mathrm{O} \%{ }_{[\mathrm{SMOW}]}$. The isotopic data preserved in the speleothems of the Soreq Cave was based on carbonate in rainfall that could not yield values more negative than -6 $\delta^{18} \mathrm{O} \%$ [PDB]. Much more striking was the carbonate isotopic data presented for a very well-dated and densely sampled interval from approximately $200 \mathrm{BCE}$ to 600 CE (Roman to Byzantine periods). During this time period much more negative oxygen isotope average values extending to $-8.5 \delta^{18} \mathrm{O} \%{ }_{[\mathrm{PDB}]}$ (Figure 1, \# 4) are presented [15, Figure 6]. These new data now prove that the climate during this crucial period was much wetter than today's rainfall between $800-1200 \mathrm{~mm}$ annually. These negative values, previously considered as indicating "forgery," are now taken as prima facie evidence of climate change. During this period of more intense rainfall the rainout effect lead to greater $\delta^{18} \mathrm{O}$ depletions in the average annual rainfall. Data that had been directly measured on speleothems from this time can't reject the authenticity of the JO and the JI. The new more negative oxygen isotopic data of [15] during the Roman to Byzantine periods contradicts the forgery determination of Ayalon [1,2].

\section{Discussion}

The assumption that patina formation on the artifacts is similar to speleothem formation [1,2] is incorrect. Moreover, assuming that isotopic values within the carbonate of a genuine patina must be related to that of a contemporaneously formed speleothem was not established (op. cit.). A speleothem forms as calcium carbonate precipitates slowly and continuously year round from drip water, usually in a closed cave, forming stalagmites and stalactites. The carbonate in the speleothem forms under equilibrium conditions. The oxygen in the speleothem is continuously exchanging and equilibrating with the oxygen in the dissolved inorganic carbonate and the water, as well as with the water and water vapor of the constrained environment of the cave. Speleothem is a relatively pure calcium carbonate that has not undergone resolution and 
that forms in a closed environment having approximately $100 \%$ humidity, constant temperature, and is devoid of secondary carbonate input. Thus, oxygen isotopes of a speleothem can be used for assessing climatic changes [18].

The patina, on the other hand, is a thin outer layer produced by changes on the surface of a rock by weathering after long atmospheric exposure [33]. The patina includes the extraction of minerals from the stone, the sedimentation of airborne dust particles with the contribution from the burial environment, and the micro-organisms living on the stone surface. All of these biogeo-chemical activities change the morphological and mineralogical surface of the stone, including color changes. Thus, whatever adheres to the weathered surface of the object comprises the patina. The process is sporadic (not continuous as in speleothems) and the rate of accretion is not uniform. The processes can take place at the land surface or buried in the soil, as often occurs in a Tel site. Microcolonial fungi play a key role in the alteration and biological weathering of rocks and minerals and are known to concentrate and deposit manganese and iron [34,35]. They are microorganisms of high survivability, inhabiting rocks in extreme conditions, and are also known to survive in subsurface and subaerial environments. We found long-living black yeast-like fungi that form pitted embedded circular structures of 20 - $500 \mathrm{mi}-$ crons in size on the surface and inside the letters of the JI [11, Figures 9 and 10] and in the letters of the JO [36]. This biopitting is a clear evidence of geomicrobiogenic activity that covers all surfaces of the artifacts and grows very slowly over dozens to hundreds of years [11].

The isotopic composition of authigenic carbonate that might form as a precipitate on a surface would be determined by kinetic reactions. Kinetic reactions, as opposed to speleothem equilibrium reactions, will not preserve any of the original environmental oxygen isotopic signatures of the rain. The patina is composed of any mixture of substances both authigenic and allogenic. It can include the incorporation of a multitude of different particles from many sources. A patina can host clays, silts and sands of any composition, precipitated salts, including carbonates, microfossils pollen and dust. The dust represents anything that the wind can transport, from near or far locations. The content and sources of dust in Israel in general have been well studied [6] and can be a mixture of whatever carbonate particles happen to be part of the local environment and/or particles which have been transported as far as a thousand kilometers from the Saharan or Arabian deserts [6,37,38]. This composition of the various carbonate sources contribute to the atmospheric dust and soil and their oxygen isotopic composition can vary greatly. Thus, isotopic composition of the naturally occurring carbonates in the Jerusalem area can vary greatly. The negative oxygen isotopes found on both $\mathrm{JI}$ and JO could well represent natural genuine values and surely not the carbonates precipitated from rainwater. The presence of allogenic carbonate or mixtures of allogenic carbonates, as a normal component of patina does not seem to have been considered when Ayalon [1,2] declared the objects to be fakes. They did not recognize that speleothem and patina formation represent different processes. The values of the oxygen isotopes of patinas do not match a narrow rainwater range of -4 to $-6 \delta^{18} \mathrm{O}$ $\%$ [PDB] that were assumed to reveal a forgery. They proposed that lower negative values for the patina of the JO and JI either represent precipitation outside of Israel, considerably to the north, or carbonate precipitated from Jerusalem water at an elevated temperature. Therefore, it was proposed that the "forgers" ground up limestone from Jerusalem, dissolved it in hot water $\left(50^{\circ} \mathrm{C}\right)$ that would account for the negative isotopic values that they deemed anomalous.

Ilani et al. [10,11] found gold globules (1 - 4 microns in diameter) within the patina of the $\mathrm{JI}$ as well as soot dated radiometrically at about 2300 years. Goren [2] suggested that to the patina "soup" the forgers added the minute gold globules and 2 millennia old powdered charcoal to account for the radiocarbon age. When the paste was ready it was supposedly painted on. The two positive isotopic values encountered in the JI, they claimed, were the result of their sampling marine microfossils embedded in the patina. These, they reasoned, were remnants of the grinding process that did not dissolve in the boiling water; for the oxygen isotopic values are exactly within the known range of marine limestone [39]. Ayalon [1] and Goren [2] claimed to have dissolved limestone in boiling water, but, limestone does not dissolve in normal Jerusalem water, rather it precipitates in hot water. Limestone dissolves in acidic solutions not alkaline Jerusalem water. The acidity that will dissolve limestone, albeit slowly, would come from carbon dioxide in the air that dissolves in the water to form carbonic acid, preferably at low temperatures. At high temperatures the carbon dioxide gas would be driven off with carbonate precipitation. The presence of marine microfossils has a much more mundane and natural explanation. Jerusalem is situated on Cretaceous marine limestones and dolostones. The building stones were made from these carbonates that crop out all over the region as they have for thousands of years. Mechanical weathering of the marine limestone erodes out the abundant microfossils. These microscopic fossils are a large component of the local dust [6]. It would be suspicious if an object from Jerusalem did not contain this carbonate dust in its patina. Thus, the origin of the heavier isotopic values close to zero $\delta^{18} \mathrm{O} \%{ }_{[\mathrm{PDB}]}$ is mostly likely due to the presence of marine fossils in the patina. Therefore, they 
are not anomalous or evidence of forgery. In addition, it is quite easy to demonstrate that values more negative than $-6 \delta^{18} \mathrm{O} \%$ [PDB] are to be expected in patina from Jerusalem due to accretion of dust, soils and Tel remnants (particles of plaster and charcoal) from the surrounding area that can easily contribute oxygen isotopic values of carbonate that are as negative, or more so, than the values of the suggested speleothems datum line of the Soreq cave. The "speleothem model" that Ayalon [1] and Goren [2] used is not indicative of patina production in artifacts.

Oxygen isotopic data for rainfall presented by BarMatthews [18] during the last twenty years over central Israel demonstrates more variable annual amounts. The average annual rainfall for the period of 1991/1992 was $1000 \mathrm{~mm}$ of rainfall with $7.1 \delta^{18} \mathrm{O} \%$ [SMOw] indicating that in the past there were more seasons of exceptional plentiful rainfall not limited to the rigid $500 \mathrm{~mm}$ annual concept of Ayalon [1].

Let us present a few oxygen isotope values of the most obvious plausible, natural components that form the patinas. It was claimed that the surface of the JO and JI were cleaned $[5,10,16]$. Let us look at the isotopic ratios found in three of the most common commercial detergents available in Israel. These are clearly shown to be more negative [40] ranging between $-6.26 \delta^{18} \mathrm{O} \%$ to $-8.51 \delta^{18} \mathrm{O} \%$ [PDB]; Figure 1, \#5), encompassing all of the two negative values of the JI and most of the "negative anomalies" of the JO. A similar range in values (Figure 1, \#6) is found in the outcrops of the "Mottled Zone" of the Hatrurim Formation [41] found on the immediate outskirts of Jerusalem. These negative values were generated by decarbonation reactions that should be very common in Jerusalem where thermal reactions and mortar used in construction were prepared and in which carbonate rock (limestone, dolostone, or marble) was combusted in the presence of common silica minerals (e.g. quartz sands, feldspars). This resulted in the release of carbon dioxide gas whose oxygen isotopes are enriched in the heavy oxygen isotope, whereas, the calcite that is formed is enriched in the light oxygen isotope (yielding more negative $\delta^{18} \mathrm{O}$ values). Matthews and Kolodny [42] have shown this to be true for the Mottled Zone. Faure [43] shows that this is a general feature for all decarbonation reactions. Decarbonation reactions are common and can account for quite negative carbonate $\delta^{18} \mathrm{O}$ values. Thus, the combustion of the Negev Oil shales (Figure 1, \#7) yields values $\left(-5.2 \delta^{18} \mathrm{O} \%\right.$ to $-10.2 \delta^{18} \mathrm{O} \%$ [PDB]; [44]) that encompass essentially all of the "anomalous" values of both the JI and the JO range. Much more negative $\delta^{18} \mathrm{O}$ values were encountered by Dr. Aryeh Shimron (personal communication, 2008) in his research on the lime crusts on limestones from the Temple Mount that underwent conflagrations during the

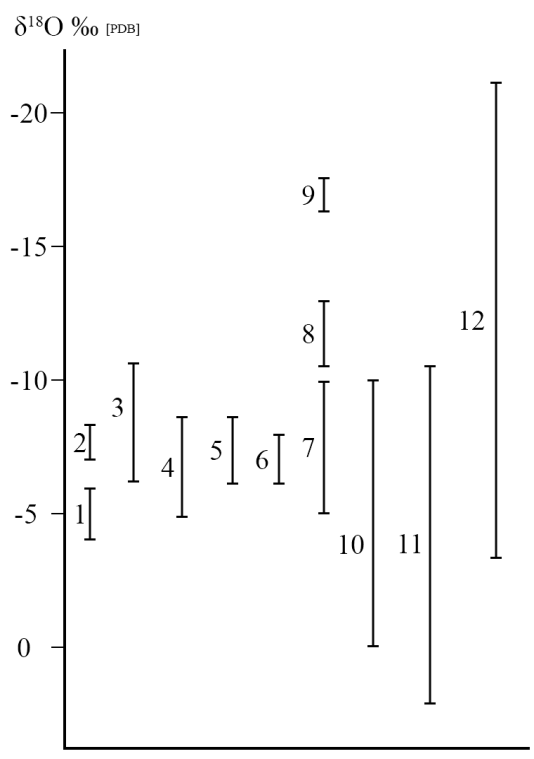

Figure 1. Oxygen isotopic ranges are as follows: 1, the speleothems of the stalagmite from the Soreq cave during the last 3000 years that corresponds to the expected values for an authentic patina according to Ayalon et al. (2004) and Goren et al. (2004); 2, the patina from the Jehoash Inscription Tablet; 3, the patina from the James Ossuary; 4, the speleothems of the stalagmite from the Soreq cave during the last 3000 years according to Orland et al. (2009); 5, commercial cleansers in Israel; 6, carbonate from the Hatrurim formation, Israel; 7, burnt oil shales; 8, lime crusts and ancient plaster from the Temple Mount; 9, calcite phytoliths having undergone decarbonation process; 10, GreekRoman marble statues; 11, Pleistocene travertines and lacustrine limestone from the Arava Valley, Israel, and from the eastern Sahara; 12, patina from 56 official excavated well-dated artifacts from Israel studied by Shemesh (2007).

destructions of the first and second Temples. The range of these values $\left(-10.7 \delta^{18} \mathrm{O} \%\right.$ to $-13.4 \delta^{18} \mathrm{O} \%$ [PDB]; Figure 1, \#8) is clearly more negative than any of the values considered to be "anomalous" to the Jerusalem area by reference to the Soreq Cave speleothems (lower than the range of $-4 \delta^{18} \mathrm{O} \%$ to $-6 \delta^{18} \mathrm{O} \%$ [PDB] $)$. Remnants of these crusts that experienced thermal events would be expected to be present in the soils of Jerusalem, especially in vicinity of the Temple Mount. Still more negative values can be found in soils (and from there to the patina in a buried object) due to the burning of wood and destruction during wars, in a Tel site (with particles of lime and plaster). Plentiful calcite phytoliths undergo decarbonation reactions that results in even more depleted values [45, Figure 1, \#9]. These phytoliths were available for subsequent incorporation into the patinas of buried objects. Statues and marble building stones were imported by the Romans. Their rubble contributed to the carbonate variations in the soils and dust of Jerusalem. The $\delta^{18} \mathrm{O} \%$ values from classical marble statues and their 
quarries from Greece and Rome [46] vary over a wide range (extended up to $-10 \delta^{18} \mathrm{O} \%$; Figure 1, \#10). Additionally, extensive outcrops of Pleistocene travertine and lacustrine limestone are found to be highly depleted in $\delta^{18} \mathrm{O}$. Winds transporting dust from the Saharan desert of North Africa or from the Arava Valley [47] of southern Israel can also contribute to the depleted $\delta^{18} \mathrm{O}$ in the patinas of the artifacts. During the Pleistocene, these hyper arid regions received rainfall from the Atlantic Ocean brought by the African Monsoons. These rainfalls filled the Nubian Sandstone aquifer which is highly depleted compared to modern rainfall [48]. The $\delta^{18} \mathrm{O}$ values of the calcite that precipitated from these paleolakes in turn can be highly depleted and can vary greatly from $-11.0 \delta^{18} \mathrm{O}$ $\%$ to $+2 \delta^{18} \mathrm{O} \%$ [PDB] [49] [49-52, Figure 1, \#11]. Once calcite grains weathered from the paleolake exposures are added to the Saharan and Arabian dusts they would become indistinguishable from other calcite grains derived from other sources.

The only oxygen isotopic study of the patina on artifacts from Israel (and probably from the world) was carried out by Shemesh [53, Figure 2]. He studied the oxygen isotopic composition of carbonate in the patina of 56 well-documented artifacts obtained from formally sanctioned archaeological excavations of the Biblical Era from the Jerusalem region and from other parts in Israel.
Out of 56 examined artifacts (ranging between -3.07 $\delta^{18} \mathrm{O} \%$ to $-22.46 \delta^{18} \mathrm{O} \%$ [PDB] 2) 12 of them (21\%) yielded $\delta^{18} \mathrm{O} \%$ values more negative than $-6 \delta^{18} \mathrm{O} \% 0[\mathrm{PDB}]$, and 11 items $(20 \%)$ exhibiting $\delta^{18} \mathrm{O} \%$ heavier than $-4 \delta^{18} \mathrm{O} \%{ }_{[\mathrm{PDB}]}$. Equally interesting was Shemesh's [53] analysis for which he took three separate samples of the patina from across the surface of one individual shard. This sampling yielded three distinctly different $\delta^{18} \mathrm{O} \%$ values. In one location at Tel Hazor (northern Galilee) the oxygen isotope amplitude of the patina ranged up to $8 \delta^{18} \mathrm{O} \%$ [PDB]. This probably indicates that we are monitoring, as previously described, a kinetic process in patina formation in which the oxygen isotopes are in disequilibrium and completely different from the mode of speleothem formation in a closed environment. According to Shemesh [53] more negative values than $-6 \delta^{18} \mathrm{O}{ }_{[\mathrm{PDB}]}$ are entirely common and indicative of a genuine patina. The carbon isotopic data from the patina's calcite exhibits wide range of distribution between $-5 \delta^{13} \mathrm{C} \%$ to $-25 \delta^{13} \mathrm{C} \%$ with no trend or connection either to geographic locations or to archaeological age [53]. Adding the $\delta^{13} \mathrm{C} \%$ values to the oxygen isotopes results does not aid in defining archaeological provenances or authentication.

It is impossible to use the isotopic composition equation as did Ayalon [1] and Goren [2] for archaeological

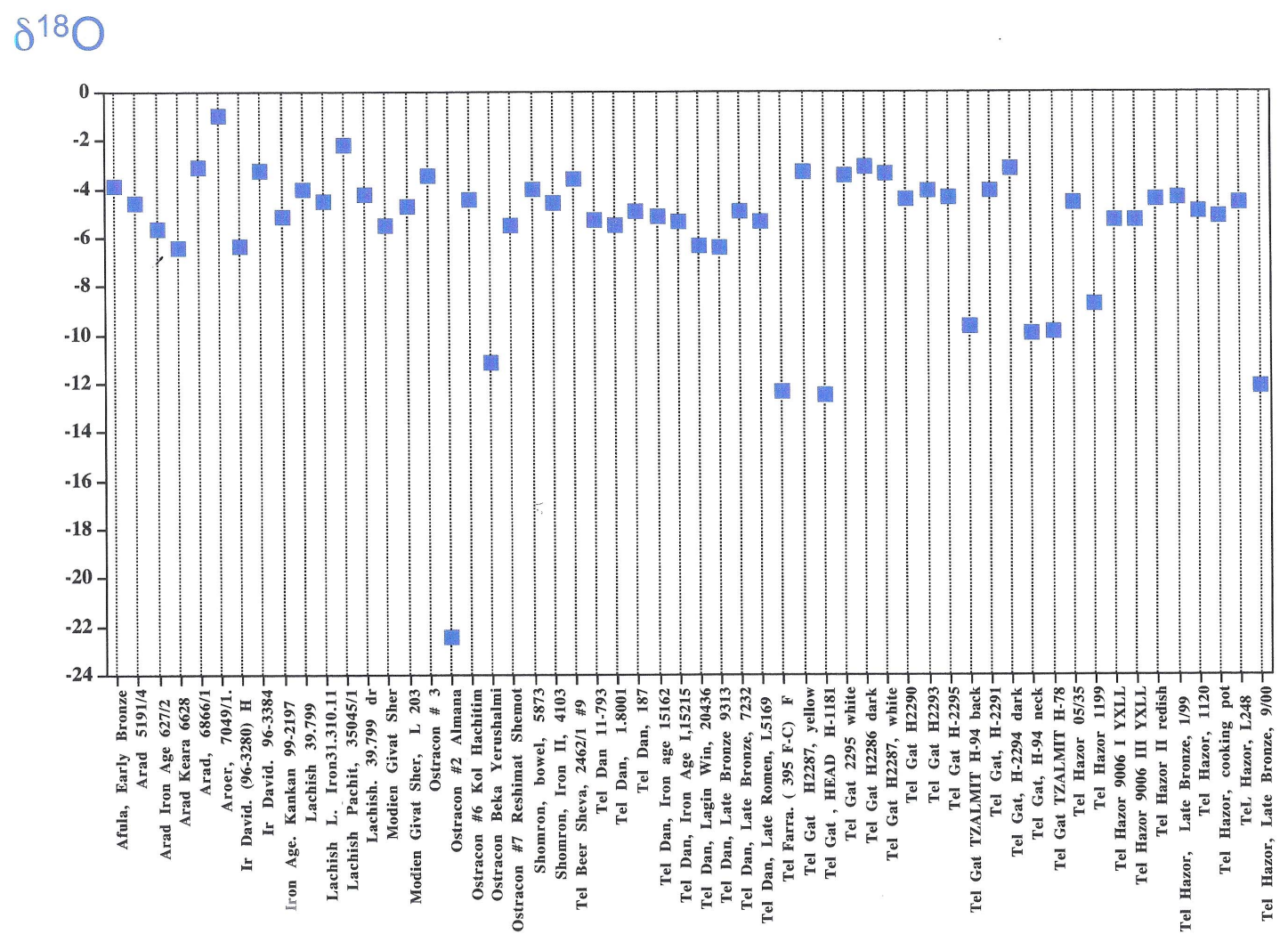

Figure 2. The distribution of oxygen isotopic composition of carbonate in the patina of 56 well-documented artifacts obtained from formally sanctioned archaeological excavations of the Biblical Era from Israel (after Shemesh, 2007). 
patinas. Indeed, now there is certainly a reason that the same oxygen isotopic values can be used to support the fact that the patinas of the inscriptions of the $\mathrm{JO}$ and the JI are authentic.

\section{Conclusion}

Patinas on artifacts collected from officially documented excavations indicate a wide range of the oxygen isotopes. Thus, the validity for authentication of artifacts is questionable and does not support an act of forgery. The formation processes and the material included in a patina are not in any way related to precipitation of speleothems purported to represent the unique composition of Jerusalem rainfall. The patina on the artifacts can be readily explained by the accretion of materials from the environment related to geo-biochemical formational processes. The speleothem-patina connection is not valid. The level of our understanding of the mechanism creating the patina and the processes that determine the oxygen isotopic composition is not yet developed enough and is insufficient to maintain that a new scientific tool allows identification of a forged patina. Moreover, we agree with Shemesh [53] and Judge Farkash's verdict $[12,13]$ that it is sufficient to establish reasonable scientific doubt about the validity of the isotopic examination used to detect archaeological forgeries. Thus, the archaeometric research applied to the JI and the JO $[5,7,11]$ strengthens the contention that both inscriptions of the Jehoash Inscription and James Ossuary are probably authentic. In the future, there is a need for more research on stable isotopes which should be done on an authentic provenanced patina in order to confirm the relationship between an authentic and fake patina.

\section{Acknowledgements}

The authors wish to thank Dr. S. Ilani, Geological Survey of Israel for his comments and suggestions for improvement of the manuscript. Thanks are due to Prof. W. E. K. Krumbein, the Oldenburg University, Germany, for his contribution in examining the micro-organism on the James Ossuary and the Jehoash Inscription tablet.

\section{REFERENCES}

[1] A. Ayalon, M. Bar-Mathews and Y. Goren, "Authenticity Examination of the Inscription on the Ossuary Attributed to James, Brother of Jesus," Journal of Archaeological Science, Vol. 31, No. 8, 2004, pp. 1185-1189. doi:10.1016/j.jas.2004.03.001

[2] Y. Goren, A. Ayalon, M. Bar-Mathews and B. Shilman, "Authenticity Examination of the Jehoash Inscription," Journal of the Institute of Archaeology of Tel-Aviv University, Vol. 31, No. 1, 2004, pp. 3-16. doi: $10.1179 / 033443504787997845$
[3] A. Lemaire, "Burial Box of James the Brother of Jesus," Biblical Archaeology Review, Vol. 28, No. 6, 2002, pp. 24-33, 70 .

[4] A. Lemaire, "Critical Evaluation of the IAA Committee Reports Regarding the Ossuary Inscription," The Polish Journal of Biblical Research, Vol. 2, No. 2, 2003, pp. 29-60.

[5] A. Rosenfeld and S. Ilani, "SEM-EDS Analyses of Patina Samples from an Ossuary of "Yaeakov Son of Yossef Brother of Yeshua," Biblical Archaeology Review, Vol. 28, No. 6, 2002, p. 29.

[6] E. Ganor, J. Kronfeld, H. R. Feldman, A. Rosenthal and S. Ilani, "Environmental Dust: A Tool to Study the Patina of Ancient Artifacts," Journal of Arid Environments, Vol. 73, No. 12, 2009, pp. 1170-1176. doi:10.1016/j.jaridenv.2009.06.004

[7] A. Rosenfeld, H. R. Feldman and W. E. Krumbein, "On the Authenticity of the James Ossuary and its Possible Link to the Jesus FamilyTomb," In: J. H. Charlesworth, Ed., Proceedings of the 3rd Princeton Symposium On Judaism and Christian Origins, Jewish Views of the After Life and Burial Practices in Second Temple Judaism, Evaluating the Talpiot Tomb in Context, Jerusalem, 13-16 January 2008.

[8] V. Sasson, "Philological and Textural Observations on the Controversial Jehoashinscription," Ugarit-Forschungen, Vol. 35, 2004, pp. 573-587.

[9] C. Cohen, "Biblical Hebrew Philology in the Light of Research on the New Yeho'ash Royal Building Inscription," In: M. Lubetski, Ed., New Seals and Inscriptions: Hebrew, Idumean and Cuneiform, Sheffield, 2007, pp. 222-286.

[10] S. Ilani, A. Rosenfeld and M. Dvorachek, "Archaeometry of a Stone Tablet with Hebrew Inscription Referring to Repair of the House," Israel Geological Survey Current Research, Vol. 13, 2002, pp. 109-116.

[11] S. Ilani, A. Rosenfeld, H. R. Feldman, W. E. Krumbein, and J. Kronfeld, "Archaeometric Analysis of the Jehoash Inscription Tablet," Journal of Archaeological Science, Vol. 35, No. 11, 2008, pp. 2966-2972. doi:10.1016/j.jas.2008.06.019

[12] A. Rosenfeld, H. R. Feldman, Y. Kronfeld and W. E. Krumbein, "Implications of the 'Forgery Trial' Verdict on the Authenticity of the James Ossuary," The Bible and Interpretation, 2012.

http://www.bibleinterp.com/articles/ros368030.shtml

[13] A. Rosenfeld, H. R. Feldman, Y. Kronfeld and W. E. Krumbein, "The Jehoash Inscription Tablet-After the Verdict," The Bible and Interpretation, 2012. http://www.bibleinterp.com/articles/ros368027.shtml

[14] A. Rosenfeld and H. R. Feldman, "Archaeometric Overview of the Jehoash Inscription and James Ossuary," Biblical Archaeology Society, Special Report, 2008, pp. 3041.

[15] I. J. Orland, M. Bar-Matthews, N. T. Kita, A. Ayalon, J. Matthews and W. Valley, "Climate Deterioration in the Eastern Mediterranean as Revealed by Ion Microprobe Analysis of a Speleothem that Grew from 2.2 to $0.9 \mathrm{ka}$ in Soreq Cave, Israel," Quaternary Research, Vol. 71, No. 1, 
2009, pp. 27-35. doi:10.1016/j.yqres.2008.08.005

[16] Y. Goren, "Israel Antiquities Authority Report," The Bible and Interpretation, 2003.

http://www.bibleinterp.com/articles/Goren_report.shtml

[17] N. A. Silberbman and Y. Goren, "Faking Biblical History," Archaeology, 2003, pp. 20-29.

[18] A. Ayalon, M. Bar-Matthews and E. Sass, "RainfallRecharge Relationships within a Karstic Terrain in the Eastern Mediterranean Semi-Arid Region, Israel: $\delta{ }^{18} \mathrm{O}$ and $\delta$ D Characteristics," Journal of Hydrology, Vol. 207, No. 1-2, 1998, pp. 18-31. doi:10.1016/S0022-1694(98)00119-X

[19] M. Bar-Matthews, A. Ayalon and A. Kaufman, "Middle to Late Holocene (6500 Years Period) Paleoclimate in the Eastern Mediterranean Region from Stable Isotopic Composition of Speleothems from Soreq Cave, Israel. In: Issar, A.S., Brown, N. (Eds.), Water, Environment and Society in times of Climate Change," Kluwer Academic Publishers, Boston, 1998, pp. 203-214. doi:10.1007/978-94-017-3659-6 9

[20] C. H. Hendy, "The Isotopic Geochemistry of Speleothems-I. The Calculation of the Effects of Different Models on the Isotopic Composition of Speleothems and Their Applicability as Paleoclimatic Indicators," Geochemicaet Cosmochemica Acta, Vol. 35, No. 8, 1971, pp. 801-824. doi:10.1016/0016-7037(71)90127-X

[21] H. P. Schwartz, "Geochronolgy and Isotope Geochemistry of Speleothems," In: P. Fritz and J.-Ch. Fontes, Eds., Handbook of Environmental Isotopes Geochemistry, Vol. 2, The Terrestrial Environment, B. Elsevier, Amsterdam, 1986, pp. 271-304.

[22] J. R. Gat and W. Dansgaard, "Stable Isotope Survey of Fresh Water Occurrences in Israel and the Northern Jordan Rift Valley," Journal of Hydrology, Vol. 16, No. 3, 1972, pp. 177-212. doi:10.1016/0022-1694(72)90052-2

[23] J. R. Gat and I. Carmi, "Effect of Climate Changes on the Precipitation and Isotopic Composition of Water in a Climate Transition Zone: Case of the Eastern Mediterranean Sea Area," IAHS, Wallingford, 1987, pp. 513-523.

[24] B. Schilman, M. Bar-Matthews, A. Almogi-Labin and B. Luz, "Global Climate Instability Reflected by Eastern Mediterranean Marine Records during the Late Holocene," Palaeogeography, Palaeoclimatology, Palaeoecology, Vol. 176, No. 1-4, 2001, pp. 157-176. doi:10.1016/S0031-0182(01)00336-4

[25] J. R. Gat and I. Carmi, "Evolution of the Isotopic Composition of Atmospheric Waters in the Mediterranean Sea Area," Journal of Geophysical Research, Vol. 75. No. 1-4, 1970, pp. 3039-3048. doi:10.1029/JC075i015p03039

[26] J. R. Gat, "The Isotopes of Hydrogen and Oxygen in Precipitation," In: P. Fritz and J.-Ch. Fontes, Eds., Handbook of Environmental Isotopes Geochemistry, Vol. 1, The Terrestrial Environment, A. Elsevier, Amsterdam, 1980, pp. 21-48.

[27] I. D. Clark and P. Fritz, "Environmental Isotopes in Hydrology," 2nd Printing, Lewis Publishers, Boca Raton, 1999.

[28] K. Rozanski, L. Araguás-Araguás and R. Gonfiantini,
"Isotopic Patterns in Modern Global Precipitation," In: Continental Isotope Indicators of Climate, American Geophysical Union Monograph, 1993

[29] A. Frumkin, D. C. Ford and H. P. Schwarcz, "Continental Oxygen Isotopic Record of the Last 170,000 Years in Jerusalem," Quaternary Research, Vol. 51, No. 3, 1999, pp. 317-327. doi:10.1006/qres.1998.2031

[30] A. Frumkin, D. C. Ford and H. P. Schwarcz, "Paeloclimate and Vegetation in the Glacial Cycles in Jerusalem from a Speleothem Record," Global Biogeochemical Cycles, Vol. 14, No. 3, 2000, pp. 863-870.

doi:10.1029/1999GB001245

[31] Y. Kolody, M. Stein and M. Machlus, "Sea-Rain-Lake Relation in the Last Glacial East Mediterranean Revealed by $\delta 0-18-\delta C-13$ in Lake Lisan Aragonites," GeochemicaetCosmochimica Acta, Vol. 69, No. 16, 2005, pp. 40454060. doi:10.1016/j.gca.2004.11.022

[32] S. McGarry, M. Bar-Mathews, A. Mathews, A. Vaks, B. Schilman and A. Ayalon, "Constraints on Hydrological and Paleotemperature Variations in the Eastern Mediterranean Region in the Last 140 ka Given by the $\delta$ D Values of Speleothem Fluid Inclusions," Quaternary Science Reviews, Vol. 19, No. 7-8, 2004, pp. 919-934.

doi:10.1016/j.quascirev.2003.06.020

[33] K. K. E. Neuendorf, J. P. Mehl Jr. and J. Jackson, "Glossary of Geology," 5th Edition, American Geological Institute, Alexandria, 2005, $779 \mathrm{p}$

[34] W. E. Krumbein and K. Jens, "Biogenic Rock Varnishes of the Negev Desert (Israel) an Ecological Study of Iron and Manganese Transformation by Cyanobacteria and Fungi," Oecologia, Vol. 50, No. 1, 1981, pp. 25-38. doi:10.1007/BF00378791

[35] A. Gurbushina, "Microcolonial Fungi: Survival Potential of Terrestrial Vegetative Structures," Astrobiology, Vol. 3, No. 3, 2003, pp. 543-554. doi: $10.1089 / 153110703322610636$

[36] W. E. Krumbein, "Preliminary Report: External Expert Opinion on Three Stone Items, n.p," Biblical Archaeology Review, "Finds or Fakes" Biblical Archaeology Society Web-Site, 2005

[37] E. Ganor, "Atmospheric Dust in Israel-Sedimentological and Meterological Analysis of Dust Deposition," Ph.D. Thesis, Hebrew University of Jerusalem, Jerusalem, 1975.

[38] D. H. Yaalon and E. Ganor, "East Mediterranean Trajectories of Dust Carrying Storms from the Sahara and Sinai," In: E. Morales, Ed., Scope 14: Saharan Dust (Mobilization, Transport, Deposition), John Wiley, New York, 1979.

[39] M. Magaritz, "Carbon and Oxygen Isotopic Composition of Some Carbonate Rocks from Israel," Ph.D. Thesis, Weizmann Institute of Science, Rehovot, 1973.

[40] J. Harrell, "Was Cleanser Used to Clean the James Ossuary Inscription?" Biblical Archaeological Review, Vol. 1, 2005, pp. 54-56

[41] Y. Kolodny and S. Gross, "Thermal Metamorphism by Combustion of Organic Matter: Isotopic and Petrological Evidence," Journal of Geology, Vol. 82, No. 4, 1974, pp. 489-506. doi:10.1086/627995 
[42] A. Mathews and Y. Kolodny, "Oxygen Isotope Fractionation in Decarbonation Metamorphism: the Mottled Zone event," Earth and Planetary Science Letters, Vol. 39, No. 1, 1978, pp. 179-192. doi:10.1016/0012-821X(78)90154-1

[43] G. Faure, "Principle of Isotope Geology," 2nd Edition, John Wiley and Sons, New York, 1986.

[44] O. Yoffe, Y. Nathan, A. Wolfarth, S. Cohen and S. Shoval, "The Chemistry and Mineralogy of the Negev Oil Shale Ashes," Fuel, Vol. 81, No. 9, 2002, pp. 1110-1117. doi:10.1016/S0016-2361(02)00021-2

[45] R. Shahack-Gross, A. Ayalon, P. Goldberg, Y. Goren, B. Ofek, R. Rabinovich and E. Hovers, "Formation Processes of Cemented Features in Karstic Cave Sites Revealed Using Stable Oxygen and Carbon Isotopic Analyses: A Case Study at Middle Paleolithic Amud Cave, Israel," Geoarchaeology, Vol. 23, No. 1, 2008, pp. 43-62. doi:10.1002/gea.20203

[46] H. Herz, "Carbon and Oxygen Isotopic Ratios: A Data Base for Classical Greek and Roman Marble," Archaeometry, Vol. 29, No. 1, 1987, pp. 35-43. doi:10.1111/j.1475-4754.1987.tb00395.x

[47] A. Livnat and J. Kronfeld, "Pleistocene Lakes in the Arava Rift of Israel (Sayif Formation); Facies and Paleoenviron-Mental Setting," Journal of African Earth Sciences, Vol. 10, No. 3, 1990, pp. 409-420. doi:10.1016/0899-5362(90)90094-U

[48] C. Sonntag, E. Klitzch, E. P. Lohnert, E. M. El Shazly, K. O. Münnich, C. Junghans, U. Thorweihe, K. Weistroffer, and F. M. Swailem, "Paleoclimate Information from Deuterium and Oxygen-18 in Carbon-14 Dated North Saharan
Groundwaters," International Atomic Agency, Neuherberg, 1978, pp. 569-580.

[49] M. A. Geyh and F. Thiedig, "The Middle Pleistocene Al Mahruqah Formation in the Murzuq Basin, Northern Sahara, Libya Evidence for the Orbitally-Forced Humid Episodes during the Last 500,000 Years," Palaeogeography, Palaeoclimatology, Palaeoecology, Vol. 257, No. 1-2, 2008, pp. 1-21. doi:10.1016/j.palaeo.2007.07.001

[50] J. M. Kieniewicz and J. R. Smith, "Hydrologic and Climatic Implications of Stable Isotope and Minor Element Analyses of Authigenic Calcite Silts and Gastropod Shells from a Mid-Pleistocene Pluvial Lake, Western Desert, Egypt," Quaternary Research, Vol. 68, No. 3, 2007, pp. 431-444. doi:10.1016/j.yqres.2007.07.010

[51] J. R. Smith, R. Giegengack and H. P. Schwarcz, "Constraints on Pleistocene Climates Through Stable-Isotope Analyses of Fossil Spring Tufas and Associated Gastropods, Kharga Oasis, Egypt," Palaeogeography, Palaeoclimatology, Palaeoecology, Vol. 206, No. 1-2, 2004, pp. 157-175. doi:10.1016/j.palaeo.2004.01.021

[52] M. Sultan, N. C. Sturchio, F. A. Hassan, F. A. Hamdan, A. Mahmoud and Z. Alfy, "Precipit Ation Source Inferred from Isotopic Composition of Pleistocene Ground Water and Carbonate Deposits in the Western Desert of Egypt," Quaternary Research, Vol. 48, No. 1, 1997, pp. 29-37. doi:10.1006/qres.1997.1907

[53] A. Shemesh, "A Report on the Composition of Oxygen Isotopes of Patinas in Archaeological Artifacts as an Indicator for Authenticity," Environmental Sciences, Weitzman Institute for Science, Rehovot, 2007. 